University of Nebraska - Lincoln

DigitalCommons@University of Nebraska - Lincoln

$10-2008$

\title{
Effect Of Intermittent Applications Of Continuous Ultrasound Signal On The Morphology And Cytoskeletal Organization In Chondrocytes
}

\author{
Anuradha Subramanian \\ Department of chemical Engineering,University of Nebraska Lincoln., asubramanian2@unl.edu \\ Sandra Noriega \\ University of Nebraska - Lincoln, snoriega2@unl.edu \\ Gulnara Hasanova \\ University of Nebraska - Lincoln
}

Follow this and additional works at: https://digitalcommons.unl.edu/cbmesubramanian

Part of the Chemical Engineering Commons

Subramanian, Anuradha; Noriega, Sandra; and Hasanova, Gulnara, "Effect Of Intermittent Applications Of Continuous Ultrasound Signal On The Morphology And Cytoskeletal Organization In Chondrocytes" (2008). Anuradha Subramanian Publications. 5.

https://digitalcommons.unl.edu/cbmesubramanian/5

This Article is brought to you for free and open access by the Chemical and Biomolecular Research Papers -- Faculty Authors Series at DigitalCommons@University of Nebraska - Lincoln. It has been accepted for inclusion in Anuradha Subramanian Publications by an authorized administrator of DigitalCommons@University of Nebraska - Lincoln. 
Published in Journal of Biotechnology 136, Supplement 1 (October 2008), Biotechnology for the Sustainability of Human Society - IBS 2008 Abstracts, 13th International Biotechnology Symposium and Exhibition, pp. S118-S125; doi 10.1016/j.jbiotec.2008.07.248 Copyright (C) 2008 Elsevier B.V. Used by permission. http://www.elsevier.com/locate/jbiotec

Published online October 16, 2008.

SESSION II-1 AdVANCES IN TISSUE ENGINEERING - INTERFACING CELlular DeVELOPMENT AND BIOMATERIALS

\title{
Effect of intermittent applications of continuous ultrasound signal on the morphology and cytoskeletal organization in chondrocytes
}

\author{
Anu Subramanian, Sandra Noriega, and Gulnara Hasanova \\ University of Nebraska-Lincoln, USA \\ Corresponding author - A. Subramanian, asubramanian2@unl.edu
}

The cellular component of the articular cartilage, chondrocytes, have long been recognized as strain-sensitive cells, and have the ability to sense mechanical stimulation through surface receptors and intracellular signaling pathways. In the present study, a continuous ultrasound wave for predetermined time intervals was employed, as opposed to pulsed-ultrasound used in previous studies, to stimulate chondrocytes seeded in 3D scaffolds. Chondrocytes seeded in 3D scaffolds $(n=6)$ were subjected to stimulation by US as follows: $1.5 \mathrm{MHz}$ for $161 \mathrm{~s}$, $5.0 \mathrm{MHz}$ for $51 \mathrm{~s}$ and $8.5 \mathrm{MHz}$ for $24 \mathrm{~s}$ and the US signal was applied twice in a 24-h period. Non-US stimulated scaffolds served as the control. Both control and US stimulate groups were maintained in culture for 10 days and at the conclusion of the culture period chondrocytes were assayed for the total DNA content, morphology, and cartilage specific gene expression by RT-PCR. Our results show that chondrocytes when stimulated with continuous US for predetermined time intervals, possessed 1.2-1.4 times higher cellular viability than control and had higher levels of type-II collagen and aggrecan mRNA expression when compared to controls ${ }^{1}$. In the present study the impact of US stimulation on the morphology, ultrastructure and the cytoskeletal organization of chondrocytes maintain in 3D scaffolds, has now been evaluated. Results depicted in Fig. 1 show that chondrocytes remain spherical after US stimulation, with an increased deposition of matrix upon US stimulation and this is consistent with the SEM micrographs of normal chondrocytes. The cytoskeletal elements under US stimulation were visualized by immunofluorescence analysis, and a few selected panels are shown in Fig. 2. Results show that in control, non-stimulated chondrocytes, actin was distributed throughout the cytoplasm and long fibers were observed (panel A), Upon US stimulation, we observed that the organization of actin fibers was redistributed, actin formed a cortical ring, long fibers were absent in most panels 
(panel B). Interestingly, when ROCK inhibitor was included, actin was diffuse and punctuate and fibers were not observed (panel C). We have observed that in control cells, nuclei were ellipsoidal and possessed the highest fluorescent intensity (panel A). Upon US stimulation, nuclei were still ellipsoidal with lighter fluorescent intensity when compared to control. Based on our results, we suggest that US stimulation alters nuclear shape, perhaps the nuclear architecture, cytoskeletal organization and gross cellular morphology. 